\title{
VTN wt Allele
}

National Cancer Institute

\section{Source}

National Cancer Institute. VTN wt Allele. NCI Thesaurus. Code C51232.

Human VTN wild-type allele is located within $17 q 11$ and is approximately $3 \mathrm{~kb}$ in length.

This allele, which encodes vitronectin protein, plays a role in the promotion of cellular adhesion and spreading and protease inhibition. 